\title{
LUCERNE SEED PRODUCTION
}

\section{G. A. AVERY, Grassmere}

Lucerne is grown for seed chiefly in Marlborough and North Canterbury with a small amount in Mid Canterbury. The variation in the areas harvested from year to year indicates two important factors regarding lucerne seed production:

1. That most farmers regard lucerne as a catch crop.

2. The terrific influence climatic conditions have on seed yield.

Certified seed areas in the last three years varied from 2,400 acres to 3,000 and back to 2,600 acres. There is also an appreciable amount of uncertified seed produced. In Marlborough it varies from about a third to half the total lucerne seed produced. Total machine-dressed seed for New Zealand ranges from 170 tons to 215 tons. The average area for each line of certified seed is from 10 to 12 acres, which shows that small selected areas on farms arc chosen for seed production. In Marlborough most seed areas are found over the Wairau plains up to Renwick and Omaka and in valleys scattered over the Awatere County.

In my own area lucerne seed is regarded as a part of the farming programme and those farmers with suitable areas leave them for seed production each year. My own farm has produced lucerne seed each year with one exception for 50 years. During the 1957-58 drought it is interesting to note that the yield of lucerne for New Zealand was high, many farmers selling extra stock rather than graze their lucerne seed stands.

\section{Soil Types}

Lucerne will produce seed on a large range of soil types. The area bordering the salt flats of Lake Grassmere, the clay-based valleys about Awatere County, rich river flats, "downy" hill country, and the heavy soils of the lower Wairau plain to the lighter soils of the Omaka have all at times produced good crops of lucerne seed. In very dry years the heavier soils maintain a steady growth suitable for seed set, while in wetter seasons the more porous lighter soils and slopes produce good seed crops.

\section{Place in Rntation}

During your trip yesterday you passed a lucerne stand at least 40 years old. To fit that into a farm rotation system would be almost impossible. This stand has not regularly been left for seed, but did produce seed only a few years ago. 1 have seen a good 
seed crop from an 18-year-old stand. The average life of most stands is about eight to 10 years. Thirty years ago many stands were renewed with only one or two seasons cropping between, but with the spread of pests which attack lucerne, a longer period (with two or three years pasture included) seems to be well worth while. Heavy cropping before sowing does not seem 'to hurt a stand grown for seed production,

\section{Seed Bed Preparation and Sowing}

A stand which establishes quickly will be quick to produce seed. One which struggles against weeds, poorly worked soil, other crops, or cover crops will suffer a setback for seed production for at least one season and sometimes for the life of the stand. A well worked seedbed with a fine tilth rolled firm is still the best way to establish a seed stand. If inoculation and fertilisers assist establishment in your area, I would say by all means use them.

My own area has not shown responses at all and a soil test of the area you will shortly see on a slide gave a $\mathrm{pH}$ of 7.2 , with calcium, potash, and phosphate at a high level.

Spring sowing enables the young plant to develop with the moisture and warmth in its favour. Stands have been successfully established in autumn with oats or barley as a cover crop. Lucerne is often oversown on crops of peas and at times with rape and turnips. Where pure stands for seed are the ultimate aim I prefer to see it sown on its own. Drilling seems to bc the most reliable method. On heavier soils about $6 \mathrm{lb}$ per acre is a good sowing for seed stands. I have successfully used sowings as low as $3 \frac{1}{2} \mathrm{lb}$ per acre broadcast. If $1 \mathrm{lb}$ per acre grew, this would be thicker than the densest stand I have seen; $1 \mathrm{lb}$ per acre is about 45 seeds per square yard and counts of three paddocks which produced good yields this last season averaged 9, 12, and 20 plants per square yard. True, such stands are susceptible to weed infestation, but that is part of the cost of a larger seed return.

It is amazing how single crowns will spread after a year or two, and the hay yield after the first season, though perhaps a little more stemmy, is just as heavy. Single crowns grow to 12 in. across, whereas in a dense stand they are only 2 to $4 \mathrm{in}$. across. These large crowns send up vigorous shoots, which are essential for seed production. Thick stands tend to send up spindly shoots, which set seed on perhaps only one flower at the top of the stem.

\section{Management of Stand}

Most stands are cut twice for hay and then left for seed. The first cut taken in October, the second in early December, and the stand is then left for seed. The seed is harvested about April and 
the stand often produces late autumn and early spring grazing in addition.

I like to graze a stand hard after the second cut so that all shoots come direct from the crown of the plant rather than shoots from cut hay stems. This is not always practical if the second cut has been delayed in being taken off the field; 7 to 20 December seems a good time to close a stand for seed in most seasons. In some areas good seed is produced after only one cut taken in November. Heavy grazing in winter does not hurt a stand from a seeding point of view.

Much depends on the weather. A stand that starts off with a hardened dark green growth is more likely to produce seed than one with soft vigorous growth after an inch or so of rain. If it can bc done early enough, it often pays to graze such a growth. Again, too much rain after the first seed has set produces what we term a "second growth", which seems to sap the reserves of the plant with the result that many of the flowers fall off and often the seed already set does not develop properly.

\section{Seed Setting}

Bees are said to have a large influence on seed yields. Much work has been done along these lines and the short-tongued bumble bee (Bomus terrestrus) is the most useful. Among the honey bees only the pollen collectors will trip or open the flower for pollination. (I have yet to be convinced of the importance thet is placed on bees, although I do what I can to encourage them and would not risk damaging them with sprays.)

Bees alone will not produce a seed set; conditions need to be right for the plant first. A lucerne flower that does not remain fresh will nearly aways drop off. However, given a flower which will develop into a pod, pollination by bees probably increases the number of seeds in each pod.

\section{Insect Pests}

Many years ago yields of 4 x $240 \mathrm{lb}$ bags of seed per acre were common. Today yields of $3 \times 160 \mathrm{lb}$ sacks of dressed seed per acre are uncommon. Only half as much; why the difference? It is not that the soil is getting cropped out with lucerne, as new areas are not producing any better than the old.

I am convinced the answer lies with insect pests-insects that suck the sap from the buds which then fail to develop and insects that suck the flowers, causing them to fall. (This is quite different from flowers falling because the plant has overgrown its capacity to maintain a healthy, fresh flower.) Then there are insects which pierce the seed pod and suck the sap from the developing seed. 
There are leafroller caterpillars and caterpillars that eat flowers, green pods, and later the seed before it hardens. Most seed crops are subject to a slight infestation of all these pests.

\section{Biological Control by Birds}

After I had had some extremely costly encounters with these pests, Mr L. Gurr, who at the time was with D.S.I.R. attached to the Cawthron Institute, Nelson, suggested biological control. May 1 here put in a plea for the sparrow? Attracting sparrows with wheat fed out from gateways and fence lines into the standing crop results in extremely efficient control. Nothing would have pleased me more than to have had a slide of a flock of sparrows at work in a stand. However, when I knew this paper was coming up, the season was too far advanced to obtain such a slide.

I have seen two flocks of sparrows work continuously from soon after 5 a.m. until 7 p.m.; not the same birds all the time, as some were coming and others going, but the flock remained intact and covered four paddocks like pea roguers. If the flock remained in one spot for more than a couple of minutes, an inspection of the area revealed insect or caterpillar damage, but seldom were there any pests remaining.

The starling is another valuable bird for pest control, but in only extreme conditions, such as occurred during the 1957--58 drought, will he enter a standing crop.

A native shield bug has become one of the worst pests in the last few years. The hedgehog eats this insect, but birds do not attack it to any extent.

\section{$H$ arvesting}

Harvesting is usually done by mowing the crop and picking up heading from the windrow. As the seed pods break off very readily when dry, I find it worth while to mow while the dew is on the crop, using an inner and outer swath board followed by a light roller to leave the crop in a narrow, compact row ready for the header. A set of lifters rather than a rotary pickup reduces further loss through handling. More seed is lost in harvesting than is often realised. When the crop is dry the seed thrashes easily and a drum setting as wide as that used for wheat will prevent damage to the seed without any loss.

The stand can bc cut when the last pods change from green to a yellowish brown; several days' drying is then necessary. If all the pods are allowed to become brown or black, only a few hours drying is necessary. This is an advantage in showery or windy seasons. 
Some people, especially some contractors, prefer to direct head the crop. This requires the crop to stand until the straw is drying off and must be done before any undergrowth becomes too long. If such seed needs further drying, hanging bags over a fence and turning them regularly is by far the best method.

\section{Yields}

Average yields are from 100 to $200 \mathrm{lb}$ per acre, with some grower each year reaching 400 to $500 \mathrm{lb}$. Then there are always a few crops which for various reasons are only barely worth harvesting.

My best yields followed a wet spring, but the crop had no rain apart from showers of 10 to 15 points from the second hay cut till harvest was complete. Very little of the straw grew more than 8 in. high, but was covered with well filled pods. Such conditions would favour only a few growers, just as wet conditions favour only those with well drained soils.

Seed purity is of great importance and the use of selective weedkillers can be of real assistance in keeping weeds out of seed areas. However, so far we have nothing that does not have a slight effect on the lucerne stand, and when spraying is being carried out I always make a point of applying the weedkiller early. I like to do mine in September. The removal of weed seeds from harvested lines is not only costly, but often causes substantial loss of good seed. 